\title{
THE EFFECT OF ENGLISH SONG LYRICS IN TEACHING VOCABULARY TOWARDS STUDENTS' LISTENING COMPREHENSION AT THE THIRD GRADE STUDENTS OF SMPN 3 GUNUNGSARI IN ACADEMIC YEAR 2017/2018.
}

\author{
Muhamad Sarifuddin \& Intan Kurniawati \\ Dosen Pendidikan Bahasa Inggris IKIP Mataram \\ Email : dgreat_ngloriousone@yahoo.com; intansamawa95@gmail.com
}

\begin{abstract}
This research is an Experimental research. This research is aimed at finding out the effect of English song lyrics in teaching vocabulary towards students' listening comprehension at the third grade students of SMPN 3 Gunungsari in academic year 2017/2018. The total of population in this study at third grade students of SMPN 3 Gunungsari in academic year 2017/2018were 46 students which divided into two classes, these are IX A 23 students and IX B 23 students. Where all of the population was taken into sample then the researcher found that IX A 22 students as the experimental group and IX B 22 students as the control group. The data of this research were collected through given pre-test and post-test for both of the sample. The researcher gave the test multiple choice for the students in English song lyrics as before and after giving the treatment. The multiple choice consist of 25 items. The score for the students' correct answer the reseacher gave1 and the incorrect gave 0 . To determine the student score, so the number of true scores divided by the total of questions and multiplied by 100. Technique of data analysis of this research was descriptive quantitative.From the computation of the students' mean and deviation scores of the two groups the researcher found that the mean score of experiment group was 37,04 and the mean score of control group was 32,35 meanwhile, the standard deviation score of experiment group was 39,1 and the standard deviation score of control group was 34,74, and the squared standard deviation score of experiment group was 1528,696 and the squared of standard deviation score of control group was 1206,609. In this study, the researcher used t-test to test the significance of the two variables being investigated, the result of t-test was compared to the t-table.After calculating the data by using t-test formula, the result was 0,23 as $t_{\text {obtained }}$. This has been proved by analyzing data from the distinction between both mean and deviation scores of experiment and control group and also by analyzing the t-test formula was obtained to t-table 1,680 at the level of significance 0,05 and degree of freedom $23+23-2=44$. After comparing the scores, that was proved that teaching vocabulary through English Song Lyrics was not effective at SMPN 3 Gunungsari in academic year 2017/2018.
\end{abstract}

Key Terms : Teaching vocabulary and English song lyric.

\section{INTRODUCTION}

Listening is an important elementin the conversation of learning English because the peopleshould be able to know what the other people are saying. It means that, in listening the people should be really understand the words thatthey hear because listening is about understanding in hearing English. Whether it is directly or through media like song or movies.

In additon, vocabulary is very important in studying English for supporting the ability of the fourth language skill (listening, speaking, reading and writing). Without mastering vocabulary, learners get difficulties to improving the ability of communication with others.

There are many problems that occured when the researcher taught during teaching practice at the ninth grade students of SMPN 3Gunungsari, LombokBarat. The researcher found that the students still have difficulties in listening such as less of vocabulary, difficult to remember vocabulary or sentence in the long-term and comprehension that the students hav not the ability to evaluate that they heard. The researcherobserved that the student had given the method by their teachers like write down on the whiteboard and ask the students to memorized those words. Sometimes, when teaching and 
learning process, students'lack of interest about what the teacher explain, because they thinks that learn English very difficult and hard to membering the new words while they never used before, and also they felt bored and got sleepy during the teacher explain in the classroom.So, the tearchers need a strategy in the teaching and learning English especially listening comprehension and vocabulary. In this case, the researcher chooses English song lyrics in teaching vocabulary towards students' listening comprehension because listen to English songs with its lyrics has a benefit for students is to increase the students' understanding in vocabulary in learning English and make it easier to remember the new vocabulary. In addition to the benefits that are directly related to the English language itself, the students get a pleasant learning condition.

Based on the explanation, the researcher tries to apply the strategy related with students's listening comprehension in English teaching and learning. That the reason why the researcher has chosen the tittle "The Effect of English Song Lyrics in Taching Vocabulary Towards Students' Listening Comprehension at SMPN 3 Gunungsari, Lombok Barat. By this strategy, the writer hope that students at SMPN 3 Gunungsari could increase their ability in vocabulary and listening comprehension because its easy to remember the new words on their mind in learning English.

Based on the background of the study above, the research problem of this study is: "Does English Song Lyrics has positive effect in teaching Vocabulary towards Students' Listening Comprehension?"

Concerning the statement of the problem above the purpose of the study in this research is:

"To find out the positive effectof English Song Lyricsin Teaching Vocabulary towards Students' Listening Comprehension."

\section{RESEARCH METOD}

This study used a quantitative research. Where quantitative research is based on the measurement of quantity or amount. It is applicable to phenomena that can be expressed in terms of quantity (Kothari, 2004: 3). This study used a experimental research with form Quasi experiments. Where in this research quasi, the researcher used non-equivalent control group design in order to examine the effect of English song lyrics in teaching vocabulary towards students' listening comprehension. According to Nunan in Imran (2015: 4) "quasi experiments have pretest and post test and there is a control group". In other words, this study using Control-Group Pretest-Postest Design in before and after giving the treatment to know whether there were differences between the experimental group and the control group. While, the experimental group treated by using English song lyric and the control group treated by using audio speech English.

\section{Population}

According to Sugiyono (2016: 61) "population is a generalization region with consisting of the object/subject that has certain qualities and characteristics that set by the researchers to be studied and then drawn the conclusions". The total of population in this study at third grade students of SMPN 3 Gunungsari in academic year 2017/2018were 46 students which divided into two classes, these are IX A 23 students and IX B 23 students

\section{Sample}

According to Sugiyono (2011: 81) "sample is part of the number and characteristics possessed by population". In other words, sample is partially subject/object specified taken are selected from a population to serve as the research object. Where the result of all population as the sample IX A 22 students as the experimental group and IX B 22 students as the control group.

\section{Sampling Technique}

Sampling technique is the way of researcher to collect the sample. To determine the sample to be used in this research, there are variety of sampling techniques, namely non-probability sampling and probability sampling (Sugiyono, 2016: 62). In this study, the researcher use Non-probabality Sampling with Sampling Total technique, because all members of the population are made as samples. Where the researcher determined the 
sample of this study is class IX B that consist of 22 students.

\section{Research Instruments}

In this study, the writer used a test as an instrument.

1. Vocabulary Test in Listening

In this study, the researcher gave the test multiple choice for the students in English song lyrics as before and after giving the treatment. The multiple choice consist of 25 items. The score for the students' correct answer the reseacher gave1 and the incorrect gave 0 . To determine the student score, so the number of true scores divided by the total of questions and multiplied by 100 .

\section{Techniques of Data Collection}

1. Pre-test

Pre-test is the first step in collecting the data. The writer came to the class by giving the students a set of test for the control and experimental group with te same test to test the level of students' knowledge of the material to be delivered, pre-test activities conducted before teaching activities are given. In other words, a pre-test used to know the ability of students about the lesson delivered.

2. Post-test

The post-test is the last step of collecting data. This step able to conducted after giving the treatment to the both groups with the same test. The result of this post test is compared with the result of pre-test that has been done so that will be known how far the effect or influence of teaching vocabulary that have been done, beside that also can be known what part of teaching vocabulary materials still not comprehended by majority of student.

\section{Techniques of Data Analysis}

Technique of data analysis is the way of the writer in analyzing the data. In this research the researcher used:

2. Descriptive Analysis

a. Mean

Mean is the average of data from the students with the formula below:

Mean score of experimental group $\left(X_{1}\right)$

$$
\overline{X_{1}}=\frac{\sum X_{1}}{N_{1}}
$$

Mean score of control group $\left(X_{2}\right)$

$$
\overline{X_{2}}=\frac{\sum X_{2}}{N_{2}}
$$

Where:

$\overline{\mathrm{X}}_{1}=$ Mean score

$\mathrm{X}_{1}=$ Score of pre-test

$\mathrm{N}=$ Total number of the sample

(Singh, 2006: 286)

b. Median

Median is the middle score of data with data in frequency distribution:

$$
M d=L+\frac{N / 2-F}{f} x i
$$

Where:

$\mathrm{Md}=$ Median score

$\mathrm{L}$ $=$ Exact lower limit of the median class.

$\mathrm{F} \quad=$ Total of all frequencies before the median class.

$\mathrm{f} \quad=$ Frequency of the median class.

$\mathrm{i}=$ Class interval

$\mathrm{N}=$ Total of all the frequencies.

(Singh, 2006: 290)

In addition, median is defined very simply as that value which has as many scores above it as below it. Its be happened to have an even number of scores then define the median as the point halfway between the two middle scores

c. Mode

Mode is the value in set of data which appears most frequently.Data in frequency distribution:

$$
M o=3 M d-2 M
$$

Where:

$$
\begin{aligned}
& \text { Mo = Mode } \\
& \text { Md= Median = Mean }
\end{aligned}
$$

(Singh, 2006: 291)

In addition, in the case of ungrouped data mode can be easly computed merely by looking at it. All that onehas to do is to find out the score which is repeated maximum number of times.

d. Standard Deviation

Standard deviation has function to find out the variation of data with the formula below:

$$
\sigma=\sqrt{\frac{\sum x^{2}}{N}}
$$

Where: 
$\sigma=$ Standar deviation

$\mathrm{x}=$ deviation of each score from the mean

$\mathrm{N}=$ Total number of the score

(Singh, 2006: 298)

2. Inferential Analysis

a. To test the hypothesis, the researcher use the formula:

$$
t=\frac{\left(M_{1}-M_{2}\right)}{\sqrt{\frac{\left(N_{1}-1\right) S_{1}^{2}+\left(N_{2}-1\right) S_{2}^{2}}{N_{1}+N_{2}-2} \sqrt{\frac{1}{N_{1}}+\frac{1}{N_{2}}}}}
$$

Where:

$\mathrm{t}=\mathrm{t}$-test

$\mathrm{M}_{1}=$ the mean score of

experimental group

$\mathrm{M}_{2}=$ the mean score of control group $S_{1}^{2}=$ the square deviation of

experimental group

$S_{2}^{2}=$ the square deviation of

control group

$\mathrm{N}_{1}=$ the number sample of

experimental group

$\mathrm{N}_{2}=$ the number sample of control group

$\sum \quad=$ the sum of the degree of freedom (Singh, 2006: 238)

Based on explanation above, researcher assume that to find out the effect using English song lyricsin teaching vocabulary towards students' listening comprehenesion the writer would compare the result of t-test to t-table. If the result of $t-$ test $>\mathrm{t}$-table, the null hypothesis is rejected. If the result of $t$-test $<\mathrm{t}$-table, the alternative hypothesis is received.

b. Validity of Instrument

According to Heaton (1988: 159) validity is extent to which it measures what is supposed to measure. In this study, the researcher uses content validity to measure the instrument of the study. To know the items and the course is valid or not, the researcher used the formula:

$$
\text { rpbis }=\frac{M_{p}-M_{t}}{s d_{t}} \sqrt{\frac{p}{q}}
$$

Where:

rpbis $=$ coefficient of point be serial correlation

$\mathrm{M}_{\mathrm{p}}=$ the mean score of the correct answer
$\mathrm{M}_{\mathrm{t}}=$ the mean score from the score total

Sdt $=$ Standar deviation

$\mathrm{P}=$ correct answer

$\mathrm{Q}=$ incorrect answer

c. Reability of Instrument

Reability is necessary characteristic of any good test: for it to be valid at all, a test must be first be realiable as a measuring istrument (Heaton, 1988 : 164). It means that, rability is very important to study because a test is called reliable if it is used to measure the same test in other time and plases. The formula as follows:

$$
r_{11}=\frac{N}{N-1}\left(1-\frac{m(N-m)}{N x^{2}}\right)
$$

Where:

$\mathrm{r}_{11}=$ reability

$\mathrm{N}=$ the number of items in the test;

$\mathrm{m}=$ the mean score on the test of all the testees

$\mathrm{x}=$ the standard devitiation of all the testees' scores

\section{FINDINGS}

This chapter concerns with the statistical analysis of the data obtained from the pre-test and post-test, experimental and control group. At the first step the researcher gave pre-test, the purpose was to know the students' basic knowledge about the materials. Second, the researcher gave treatments to the both groups, but different treatment. Where in experiment group used English Song Lyrics but in control group used Audio Speech. The last step, the researcher gave post-test as the last step to collect the data. To answer the problem, the researcher analyzed the data obtained from pre-test and post-test scores of both experiment and control group. Then, the researcher presented the statistical computation of mean scores of both groups. The discussion continued to analyzed and interpret the findings. The statistical computation covered the calculation of both experiment and control group.

1. Data of Experiment Group

Here was the table of data gained from experiment group from pre- test and post-test. Table 02 Table of Students' Individual's Scores Obtained from Pre-Test and Post-Test Experiment Group 


\begin{tabular}{|l|l|l|l|l|l|}
\hline N0 Name & $\begin{array}{c}\text { Total } \\
\text { score of } \\
\text { pre-test }\end{array}$ & $\begin{array}{c}\text { Total } \\
\text { score of } \\
\text { post-test }\end{array}$ & $\begin{array}{c}\text { Deviation of } \\
\text { Pre-test and } \\
\text { Pos-test(xi) }\end{array}$ & $\begin{array}{c}\text { The square of } \\
\text { the deviation } \\
(x i)^{2}\end{array}$ \\
\hline 1 & AR & 52 & 82 & 30 & 900 \\
\hline 2 & ASS & 34 & 88 & 54 & 2916 \\
\hline 3 & ADR & 52 & 92 & 40 & 1600 \\
\hline 4 & AAP & 44 & 98 & 54 & 2916 \\
\hline 5 & BOAAS & 56 & 80 & 24 & 576 \\
\hline 6 & DL & 46 & 76 & 30 & 900 \\
\hline 7 & ESP & 40 & 96 & 56 & 3136 \\
\hline 8 & H & 32 & 78 & 46 & 2116 \\
\hline 9 & HA & 56 & 80 & 24 & 576 \\
\hline 10 & IMM & 40 & 82 & 42 & 1764 \\
\hline 11 & I & 48 & 90 & 42 & 1764 \\
\hline 12 & MJ & 52 & 84 & 32 & 1024 \\
\hline 13 & MRA & 34 & 96 & 62 & 3844 \\
\hline 14 & NDYP & 68 & 94 & 26 & 676 \\
\hline 15 & RI & 28 & 76 & 48 & 2304 \\
\hline 16 & RA & 40 & 88 & 48 & 2304 \\
\hline 17 & R & 56 & 76 & 20 & 400 \\
\hline 18 & SH & 52 & 88 & 36 & 1296 \\
\hline 19 & SD & 52 & 82 & 30 & 900 \\
\hline 20 & YP & 48 & 80 & 32 & 1024 \\
\hline 21 & YWS & 62 & 90 & 28 & 784 \\
\hline 22 & F & 88 & 100 & 12 & 144 \\
\hline 23 & MTAS & 40 & 76 & 36 & 1296 \\
\hline Total & 1120 & 1972 & 852 & 35160 \\
\hline & & & & & \\
\hline
\end{tabular}

The highest score of pre-test was 88 from the total number of correct answers were 22, the highest score of post-test was 100 from the total number of correct answers were 25 and the lowest score of pre-test was 28 from the total number of correct answers were 7 , the lowest score of post-test was 76 from the total number of correct answers were 19 for the experiment group.

After the researcher showed the individual scores of the experiment group the researcher continued to find out mean, median, mode, and standard deviation score by using the formulas in preview chapter (III).

a. Mean score experimental group

$$
\begin{aligned}
& \bar{X}=\frac{\sum X_{1}}{N_{1}} \\
& =\frac{852}{23} \\
& =37,04
\end{aligned}
$$

Where:

$\overline{\mathrm{X}}_{1}=$ Mean score

$\mathrm{X}_{1} \quad=$ Score of pre-test

$\mathrm{X}_{2} \quad=$ Score of post-test

$\mathrm{N}=$ Total number of the sample

c. The Median Score of Experiment Group
To find out the median score the researcher showed the individual's scores of

\begin{tabular}{|c|c|}
\hline Pre-test & $\begin{array}{l}28,32,34,34,40,40,40,40,44, \\
46,48, \mathbf{4 8}, 52,52,52,52,52,56, \\
56,56,62,68,68 .\end{array}$ \\
\hline Post-test & $\begin{array}{l}76,76,76,76,78,80,80,80,82, \\
82,82, \mathbf{8 4}, 88,88,88,90,90,92, \\
94,96,96,98,100 .\end{array}$ \\
\hline
\end{tabular}
experimental group, the individual's scores were:

Based on the data of the individual's scores of experiment group above, it could be calculated that the median score of experiment group in pre-test was 48 , because 48 score was the middle score of pre-test and in post-test was 84 , because 84 score was the middle score of post-test.

a. The Mode Score of Experiment Group

To find out the mode score the researcher showed the individual's score of

\begin{tabular}{|c|c|}
\hline Pre-test & $\begin{array}{l}28,32,34,34,40,40,40,40, \\
44,46,48,48, \mathbf{5 2}, \mathbf{5 2}, \mathbf{5 2}, \mathbf{5 2}, \\
\mathbf{5 2}, 56,56,56,62,68,68 .\end{array}$ \\
\hline Post-test & $\begin{array}{l}\text { 76, 76, 76, 76, 78, 80, 80, 80, } \\
82,82,82,84,88,88,88,90, \\
90,92,94,96,96,98,100 .\end{array}$ \\
\hline
\end{tabular}
experimental group, the individual's scores are:

Based on the data of the individual's scores of experiment group above, it could be calculated that the mode score of experiment group in pre-test was 52 , because 52 score appeared five times of pre-test and in post-test was 76 , because 76 score appeared four times of post-test.

d. The Standard Deviation Score of Experiment Group

$$
\begin{aligned}
& \sigma=\sqrt{\frac{\sum x^{2}}{N}} \\
& =\sqrt{\frac{35160}{23}} \\
& =\sqrt{1528,696} \\
& =39,09854 \\
& =39,1 \\
& \text { Where: } \\
& \sigma=\text { Standar deviation } \\
& \text { X }=\text { deviation of each score } \\
& \text { from the mean }
\end{aligned}
$$


$\mathrm{N}=$ Total number of the score

2. Data of Control Group

Here was the table of data gained from control group from pre- test and post-test.

Table 03 Table of Students' Individual's Scores Obtained from Pre-Test and Post-Test Of Control Group

\begin{tabular}{|l|l|l|l|l|l|}
\hline NO & Name & $\begin{array}{l}\text { Total } \\
\text { score of } \\
\text { pre-test }\end{array}$ & $\begin{array}{l}\text { Total } \\
\text { score of } \\
\text { post-test }\end{array}$ & $\begin{array}{l}\text { Deviation } \\
\text { of Pre-test } \\
\text { and Pos- } \\
\text { test(yi) }\end{array}$ & $\begin{array}{l}\text { The square of } \\
\text { the deviation } \\
(y i)^{2}\end{array}$ \\
\hline 1 & AH & 32 & 76 & 44 & 1936 \\
\hline 2 & ASR & 52 & 90 & 38 & 1444 \\
\hline 3 & AHS & 40 & 88 & 48 & 2304 \\
\hline 4 & AH & 62 & 88 & 26 & 676 \\
\hline 5 & BS & 34 & 80 & 46 & 2116 \\
\hline 6 & DRI & 74 & 90 & 16 & 256 \\
\hline 7 & E & 32 & 92 & 60 & 3600 \\
\hline 8 & EMS & 34 & 76 & 42 & 1764 \\
\hline 9 & FL & 80 & 92 & 12 & 144 \\
\hline 10 & H & 42 & 88 & 46 & 2116 \\
\hline 11 & HH & 44 & 78 & 34 & 1156 \\
\hline 12 & HLH & 48 & 78 & 30 & 900 \\
\hline 13 & JA & 80 & 92 & 12 & 144 \\
\hline 14 & MDW & 62 & 76 & 14 & 196 \\
\hline 15 & MRL & 64 & 92 & 28 & 784 \\
\hline 16 & MRI & 62 & 92 & 30 & 900 \\
\hline 17 & M & 32 & 78 & 46 & 2116 \\
\hline 18 & NSS & 52 & 76 & 24 & 576 \\
\hline 19 & RN & 66 & 92 & 26 & 676 \\
\hline 20 & SS & 66 & 88 & 22 & 484 \\
\hline 21 & TJ & 48 & 90 & 42 & 1764 \\
\hline 22 & TZ & 66 & 92 & 26 & 676 \\
\hline 23 & WP & 58 & 90 & 32 & 1024 \\
\hline Total & 1230 & 1974 & 744 & 27752 \\
\hline & & & & & \\
\hline
\end{tabular}

The highest score of pre-test was 80 from the total number of correct answers were 20, the highest score of post-test was 92 from the total number of correct answers were 23 and the lowest score of pre-test was 32 from the total number of correct answers were 8 , the lowest score of post-test was 76 from the total number of correct answers were 19 for the control group.

After the researcher showed the individual scores of control group the researcher continued to find out mean, media, mode, and standard deviation score by using the formulas in preview chapter (III).

a. Mean score of control group

$$
\begin{aligned}
& \bar{X}=\frac{\sum X_{2}}{N_{1}} \\
& =\frac{744}{23} \\
& =32,35
\end{aligned}
$$

Where:

$$
\begin{array}{ll}
\overline{\mathrm{X}}_{1} & =\text { Mean score } \\
\mathrm{X}_{2} & =\text { Score of post-test } \\
\mathrm{N} & =\text { Total number of the sample }
\end{array}
$$

\begin{tabular}{|c|c|}
\hline Pre-test & $\begin{array}{l}32,32,32,34,34,40,42,44,48, \\
48,52, \mathbf{5 2}, 58,62,62,62,64,66, \\
66,66,74,80,80 .\end{array}$ \\
\hline Post-test & $\begin{array}{l}76,76,76,76,78,78,78,80,88, \\
88,88, \mathbf{8 8}, 90,90,90,90,92,92, \\
92,92,92,92,92 .\end{array}$ \\
\hline
\end{tabular}

b. The Median Score of Control Group

To find out the median score the researcher showed the individual's scores of control group, the individual's scores were:

Based on the data of the individual's scores of control group above, it can be calculated that the median score of control group in pre-test was 52 , because 52 score was the middle score of pre-test and in posttest was 88 , because 88 score was the middle score of post-test.

a. The Mode Score of Control Group

To find out the mode score the researcher showed the individual's score of control group, the individual's scores were:

\begin{tabular}{|l|l|}
\hline Pre-test & $\mathbf{3 2}, \mathbf{3 2}, \mathbf{3 2}, 34,34,40,42,44$, \\
& $48,48,52,52,58,62,62,62$, \\
& $64,66,66,66,74,80,80$. \\
\hline Post-test & $76,76,76,76,78,78,78,80$, \\
& $88,88,88,88,90,90,90,90$, \\
& $\mathbf{9 2 , 9 2 , 9 2 , 9 2 , 9 2 , 9 2 , 9 2 .}$ \\
\hline
\end{tabular}

Based on the data of the individual's scores of control group above, it can be calculated that the mode score of control group in pre-test was 32 , because 32 appeared three times of pre-test and in post-test was 92 , because 92 score appeared seven times of post-test.

b. The Standard Deviation Score of control Group

$$
\begin{aligned}
& \sigma=\sqrt{\frac{\sum x^{2}}{N}} \\
& =\sqrt{\frac{27752}{23}} \\
& =\sqrt{1206,609} \\
& =34,73627 \\
& =34,74
\end{aligned}
$$

Where:

$\sigma=$ Standar deviation

$\mathrm{X}=$ deviation of each score from the mean

$\mathrm{N}=$ Total number of the score 
c. T-test Score of the Research

The last process of the statistical data computation was to find out the value of t-test on the previous results and data computation. The data already obtained were mean score of experiment group was 37,04 and the mean score of control group was 32,35 meanwhile, the standard deviation score of experiment group was 39,1 and the standard deviation score of control group was 34,74, and the squared standard deviation score of experiment group was 1528,696 and the squared of standard deviation score of control group was 1206,609 . Those scores need to be identified by using t-test to find out the significant result of this research.

$$
\begin{aligned}
& t=\frac{\left(M_{1}-M_{2}\right)}{\sqrt{\frac{\left(N_{1}-1\right) S_{1}^{2}+\left(N_{2}-1\right) S_{2}^{2}}{N_{1}+N_{2}-2} \sqrt{\frac{1}{N_{1}}+\frac{1}{N_{2}}}}} \\
& =\frac{(37,04-32,35)}{\sqrt{\frac{(23-1) 1528,696+(23-1)) 1206,609}{23+23-2} \sqrt{\frac{1}{23}+\frac{1}{23}}}} \\
& =\frac{4,69}{\sqrt{\frac{33631,31+26545,4}{44} \sqrt{\frac{2}{23}}}} \\
& =\frac{4,69}{\sqrt{\frac{60176,71}{44}(0,30)}} \\
& =\frac{4,69}{\sqrt{1367,653(0,30)}} \\
& =\frac{4,69}{\sqrt{410,2958}} \\
& =\frac{4,69}{20,26} \\
& =0,23
\end{aligned}
$$

Where:

$\mathrm{t}$ : Computation of $\mathrm{t}$ value

$\bar{x}_{1}$ : The mean deviation score of experimental group

$\bar{x}_{2}$ : The mean deviation score of control group

$N_{1} \quad$ : The number of sample of experimental group

$N_{2}$ : The number of sample of control group
$S_{1}{ }^{2}$ : The squared standard deviation of experimental group

$S_{2}{ }^{2}$ : The squared standard deviation of control group

\section{Discussion}

Computation the students' mean and deviation scores of the two groups. It has been discussed in chapter three, how to collect data after three weeks doing research, the groups were given a test two times. Pre-test was to find out the students' listening comprehension before the treatment and post-test was given after giving treatment was to find out the significance result.

After calculating the mean scores of each group in experimental and control group in post-test, the mean score of experiment group was 37,04 and the mean score of control group was 32,35 meanwhile, the standard deviation score of experiment group was 39,1 and the standard deviation score of control group was 34,74, and the squared standard deviation score of experiment group was 1528,696 and the squared of standard deviation score of control group was 1206,609 . In this study, the researcher used t-test to test the significance of the two variables being investigated, the result of t-test was compared to the t-table.

Identifying the significance of the deviation scores from the two mean scores and the last process of computation statistical data was to find out the value of $t$, based on the previous data computation and description. After calculating the data by using t-test formula, the result was 0,23 as $t_{\text {obtained }}$.

This has been proved by analyzing data from the distinction between both mean and deviation scores of experiment and control group and also by analyzing the ttest formula was obtained to t-table 1,680 at the level of significance 0,05 and degree of freedom $23+23-2=44$. After comparing the scores, that was proved that teaching vocabulary through English Song Lyrics was not effective at SMPN 3 Gunungsari in academic year 2017/2018. 


\section{Conclusion}

From the result of investigation the researcher concluded that the data analysis showed the using of English Song Lyrics. The statistical analysis of t-test the data obtained had been done.

Based on the result of data analysis in the previous chapter (IV), the mean score of experiment group was 37,04 and the mean score of control group was 32,35 . Furthermore, the score of t-test was 0,23 and the t-table was 1,680 at the level of significance $0,05 \%$, meant that the score of t-test was lower than t-table. So, the alternative hypothesis was rejected and the null hypothesis was retained. It took conclusion that the English Song Lyrics was not effective in vocabulary towards students' listening comprehension at the nine grade students of SMPN 3 Gunungsari in academic year 2107/2108.

\section{References}

Al-Khufaishi, Adil. 1998. Vocabulary Mastery Nota Luxury.Elt From.Vol: six edition March.

Allen.1978. Researchin Education A Conceptual Introduction. NewYork. Happer Collins College Publisher.

Arikunto, Suharsimi. 1998. Prosedur Penelitian: Suatu Pendekatan Praktek (Edisi Revisi V). Jakarta:PT. Rineka Cipta.

Arikunto, Suharsimi. 2002. Prosedur Penelitian: Suatu Pendekatan Praktek (Edisi Revisi V). Jakarta:PT. RinekaCipta.

Ashby,Michael.1995. Introducing Phonetic Science.London: Oxford University Express

Borg,Walter Rand Gall, Meredith. D. 1988. Educational Research:Introduction New York and London:Longman, Inc

Carrol.1963. Thought and Language. Harvard Educational Review

Downes, William. 1998. Language and Society. Cambridge: Cambridge University Press.

Finch, Goeffrey. 1998. How to Study Linguistics. Cambridge: Cambridge University Press.
Hadi, Sutrisno.1984. Pengantar Penelitian Ilmiah. Bandung:Tarsit

Hiebert, Elfrieda H. And Kamil, Michael L. 2005.The Teaching and Learning of Vocabulary: Bringing Research to Practice. London:Lawrence Erlbaum Associates, Publishers.

http:www.adviceopedia.org/Hard_to_answer _riddles

Hornby, AS. 1983. Oxford Learners Pocket Dictionary of Current English, Oxford $11^{\text {th }}$ Impression. London:Oxford University Express Finger Dictionary

Kernerman. 2003. Semi-bilingual Dictionaries. USA

Netra, I. B. 1974. Statistik Inferensial. Surabaya: Usaha Naional Reading Resource.net

Rohman,

Robert.

1983. IntroductiontoresearchinEducation.New York:HolfRinerhatandWinston.

Sugiono.2008. Metode Penelitian Kuantitatif, Kualitatif, dan $R$ \& D. Bandung: Alfabeta

Tarigan, Guntur. 1986. Gaya Bahasa. Jakarta: Gramedia

Widdowson, H. G. 1978. Teaching Languageas Communication. London: Oxford University Express 